\section{The New British Museum Law}

The new British Museum Bill which passed its third reading in the House of Lords on April 27 has become law. It is of profound importance to all research scientists in biology and geology; but it had a meteoric flight through the House of Commons and the House of Lords. Its transit was apparently unheralded in the Press : its purport is of such national importance that it is surprising that no reference to the course it took through the Houses of Commons and Lords was available to biologists all over the world.

The Bill's second reading (Hansard, April 4, 1955, cols. 943-59) was proposed by the Financial Secretary to the Treasury (Henry Brooke), saying, "Its main purpose is to render it possible for objects in the Collection of the Natural History Museum to be lent abroad for research purposes". He was strongly supported by a Trustee, Mr. Chuter Ede, who spoke of the need to reciprocate in the loan of insects, etc., with foreign museums which lend to us. $\mathrm{He}_{\theta}$ was followed by five speakers, all congratulatory about the Bill, but not one of them made any reference whatever to type specimens, or showed that they knew of the danger to types in the Bill they were so complacently voting for.

The Bill was exceedingly short (one page) and its main purport was to allow the loan of specimens, which olways hitherto has been prohibited.

On reading Hansard, I was alarmed by the threat to type specimens in this Bill. I ascertained that important officials of the Natural History Museum were also alarmed. Communications with Mr. Chuter Ede effected nothing. The Bill was passed with no alteration on April 6 (Hansard, col. 1,305) when Mr. Ede expressed "very sincere thanks for the expedition with which the Bill has been considered".

The Manchester Guardian published a letter from me on April 19. In it I wrote : "I am horrified by the way the bill has been so rushed . . . All it needs, however, is the addition of one short clause making it clear that type specimens are reserved and are never to be lent", and I made an appeal to the Lords to save the situation.

In the House of Lords the Bill was introduced by the Lord Chancellor, read a second time, and it was then anticipated that it would go through automatically. Fortunately, Lord Chorley, alive to the danger to type specimens, proposed an amendment that they should be reserved and never lent from the British Museum. This postponed consideration for a week. Meanwhile, Sir Guy Marshall, an entomologist, wrote to the Manchester Guardian (April 23) favouring the idea that type specimens of insects should be loanable. The Manchester Guardian published my reply (April 27), in the course of which I wrote: "The Lord Chancellor, proposing the bill, referred to my letter in your issue of April 19 and gave a solemn assurance that type specimens would be carefully protected by museum regulations. But surely it is bad law-making to pass a law that at once requires regulations to counter its purport. The British Museum should be adamant in retaining its proud position as being the only place in the world where every expert can be sure of finding types on the premises were he to arrive suddenly by air with only a few hours to do the comparative work he required. Under the projected bill he might arrive counting on this and find the essential type thousands of miles away. This is deplorable".
The same day the Bill was in the House of Lords Committee stage to consider Lord Chorley's amendment, Lord Chorley moved after "Provided that", to insert: " $(a)$ the said power shall not extend to the lending of type specimens; and (b)" (Hansard for the Lords, April 27, cols. 599-603). Lord Chorley said, "your Lordships will appreciate that the type specimen, which is the very fountain of the work of research in its line, is of great importance. . . . It is true that the noble and learned Viscount went some distance in his speech on Second Reading to meet this point when he promised that the Trustees would make regulations under which type specimens would only occasionally be lent out, and $I$ and those for whom I speak are grateful for his promise in that regard. But I suggest that it is not altogether satisfactory to be content with promises of that kind".

The Lord Chancellor (Viscount Kilmuir) said he hoped the amendment would not be pressed; but he promised that, "the Trustees of the British Museum, of whom I have the honour to be one, will regard this matter most scrupulously and will use this power in respect of type specimens only in the most unusual cases".

$\mathrm{H}_{\Theta}$ was followed by the Earl of Ilchester, "the Trustees, of whom I am one, feel strongly on this point. ... I wonder whether they will ever go out ... every care will be taken to ensure that no specimen that should not go out is allowed to go".

Lord Strabolgi, supporting Lord Chorley, asked for a time-limit for loans.

He was at once answered by the Lord Chancellor, who said, "I will look into this point with pleasure"'

Lord Chorley then withdrew his amendment, and said, "So long as these points are within the vivid recollection of the 'Trustees, I am sure they will see to it that they are properly attended to".

In the course of the hurried passage of the Bill the efforts to deal with such an important matter could not be mobilized. The keepers in the Natural History Museum, who are the chief experts, each responsible for the specimens dealing with his own science, whose opinions in this matter are of prime importance, were unrepresented. I asked at least one of the keepers to come to the House of Lords before the hearing so that one or two of the Lords might be informed by expert opinion, but as British Museum officials are Civil servants it was out of the question that any of the real experts could take any part in the 'back-stage' discussion which could only be conducted with the Director of the Natural History Museum, who was out of the country.

However, the consideration shown by the House of Lords and the promises made in response to Lord Chorley's efforts are reassuring, although the types are no longer protected by law as heretofore.

But it is evident scientists should always be on the alert, and it is to be hoped that in future more time will be given to any legislation affecting scientific matters of importance.

The quotations I have made are brief, and everyone interested in the Natural History Museum should read the verbatim reports in Hansard: Commons, April 4 and 6; Lords, April 21 and 27.

Marie C. Stopes

Norbury Park,

Dorking,

Surrey.

May 3. 